Research Article

\title{
Study on the Life-Cycle Health Monitoring Technology of Water-Rich Loess Tunnel
}

\author{
Xiaohui Xue $\mathbb{D}^{1,2}$ Yongli Xie $\mathbb{D}^{1,}{ }^{1}$ and Xinxing Zhou $\mathbb{D}^{2,3}$ \\ ${ }^{1}$ School of Highway, Chang'an University, Xi'an 710064, China \\ ${ }^{2}$ Key Laboratory of Highway Construction and Maintenance Technology in Loess Region, \\ Shanxi Transportation Technology Research \& Development Co., Ltd., Taiyuan 030032, China \\ ${ }^{3}$ State Key Laboratory of Silicate Building Materials, Wuhan University of Technology, Wuhan 430070, China \\ Correspondence should be addressed to Xinxing Zhou; zxx09432338@whut.edu.cn
}

Received 17 April 2019; Revised 31 August 2019; Accepted 21 September 2019; Published 16 October 2019

Academic Editor: Antonio Caggiano

Copyright (c) 2019 Xiaohui Xue et al. This is an open access article distributed under the Creative Commons Attribution License, which permits unrestricted use, distribution, and reproduction in any medium, provided the original work is properly cited.

\begin{abstract}
The engineering properties of water-rich loess tunnel will decline sharply because of the existence of water, which threats the safety and stability of the tunnel seriously. In order to ensure the safety and stability of the Qiaoyuan tunnel, the life-cycle health monitoring was measured by the vibrating wire sensor and distributed optical fiber. The contact pressure, shotcrete stress, stress of steel arch rib, and strain states of the secondary liner were evaluated. The results of the life-cycle health monitoring demonstrated that the construction procedure, irrigation, and heavy rainfall significantly affected the mechanics morphology of the support structure. In particular, under the influence of irrigation, the shotcrete stress of the left shoulder had risen to $6.21 \mathrm{MPa}$ from $5.30 \mathrm{MPa}$. Affordable maximum tensile stress of the right shotcrete is $2.15 \mathrm{MPa}$, which caused the cracking of primary support structure with a crack width of $3 \mathrm{~mm}$ to $8 \mathrm{~mm}$. After irrigation and heavy rainfall, the stress of steel arch rib of the left haunch had risen to $135.7 \mathrm{MPa}$ and $298.7 \mathrm{MPa}$, respectively. In addition, the strain of secondary liner rose to $1498 \mu \varepsilon$ from $1278 \mu \varepsilon$ continuously at the right sidewall on section YK9 +685 , presenting that the crack was still developing. It indicates that the vibrating wire sensor and the distributed optical fiber were successful in achieving the life-cycle health monitoring of water-rich loess tunnel. This technique has a significant impact on formulating the maintaining measures and reducing the risk of tunnel.
\end{abstract}

\section{Introduction}

China has the most developed and largest loess region in the world, especially in the northwest region. In recent years, with the rapid development of traffic foundation construction, lots of loess tunnels had been constructed. There are many water-rich loess layers in the loess region under the influence of irrigation, heavy rainfall, valley terrain, and other factors. The special physical and mechanical properties of loess, such as large pores, vertical joints, and collapsibility $[1,2]$, have made its engineering properties decline sharply in the water-rich environment, which will cause tunnel lining cracks, leakage, basement uplift, and other problems during the construction and operation period [3-5]. These problems will impact the tunnel safety and reliability seriously [6-8]. Therefore, the life-cycle health monitoring technology of water-rich loess tunnel will play a very important role in reducing the construction cost and guaranteeing the operation safe.

At present, the main methods of the life-cycle health monitoring technology include vibrating wire sensor [9-13], high-accuracy electronic level [14], precision electronic total station [15], and mechanical sensor [16, 17]. The common monitoring methods of tunnel are three-dimensional (3D) laser scanner [18-20], geological radar [21, 22], and computed tomography (CT) [23, 24]. However, interrupted traffic in the process of fieldwork is required for these methods and they do not take the life-cycle health monitoring and security warning.

With the rapid development of optic fiber sensing technology, distributed fiber optic has been applied to the field monitoring of civil engineering including tunnels, slopes, and subgrade successfully. Distributed fiber optic is an ideal tool for monitoring the tunnel lining. The most popular distributed 
optical fiber sensor of tunnel health monitoring is Brillouin Optical Time Domain Reflectometry (BOTDR) currently, which has been deeply researched by domestic and foreign scholars. Fujihashi et al. [25] invented an actual system for monitoring tunnel sectional displacement and tunnel longitudinal strain in Tokyo Metro Subway Line No.13. Shi et al. [26] introduced the monitoring schemes of BOTDR in Nanjing Gulou tunnel and discussed the influence of temperature and vibration on the monitoring results. Mao et al. [27] described an air-blowing and vacuum-grouting technology embedding the distributed optical fiber sensor into tunnel lining concrete for monitoring its stress field. A pilot research conducted in Slovakia involved the installation of an optical fiber into the primary lining, and the results demonstrated that BOTDR is able to achieve structural load measurement and security monitoring in tunnel [28]. Wang et al. [29] developed an optical-based monitoring system to monitor the segment joints, which was used in the Suzhou Metro Line 1.

To obtain the stress-strain of the supporting structure and the surrounding rock, a life-cycle health monitoring system was conducted on the life cycle of the Qiaoyuan tunnel. The safety and stability of the water-rich loess tunnel were discussed based on the results of field monitoring. The effects of construction procedure, irrigation, and heavy rainfall on the nonbalanced distribution stress of the support structure were also evaluated.

\section{Materials and Experiments}

\subsection{Materials}

2.1.1. Soil Pressure Cell. As shown in Figure 1, the contact pressure between the surrounding rock and primary support was monitored by the double capsule soil pressure cell. Based on the theory of vibrating wire tension, for the pressure cell, the frequency was used as the output signal to enhance its antiinterference capability. The built-in temperature sensor could modify the effect of the external temperature fluctuations and improve the monitoring accuracy as well. Moreover, the pressure cell has two stress capsules and cushion in a smart structure. The cushion transfers the pressure from the outer capsule to the inner capsule evenly. The specific conditions and pressure cell (JMZX-5020ATm) were used in the field. In addition, the measurement ranged from $0 \mathrm{MPa}$ to $2 \mathrm{MPa}$ and the resolution is $0.01 \mathrm{MPa}$. In the process of the field installation, the pressure-bearing capsule was buried toward the surrounding rock. In order to guarantee good contacting results, the clearances among the pressure cell, surrounding rock, and primary support should be filled by fine-grained soil.

2.1.2. Concrete Strain Gauge. As shown in Figure 2, the internal force state of the concrete structure was monitored by the concrete strain gauge. Based on the theory of vibrating wire tension, the gauge has a $-2,000$ to $+2,000 \mu \varepsilon$ measurement range and accuracy to $0.5 \%$ of full scale. In field installation, the concrete strain gauge was tied up to the structural steel with the iron ribbons firmly. The installation position should be protected from construction disturbance as much as possible. Then, the conducting wire was laid out

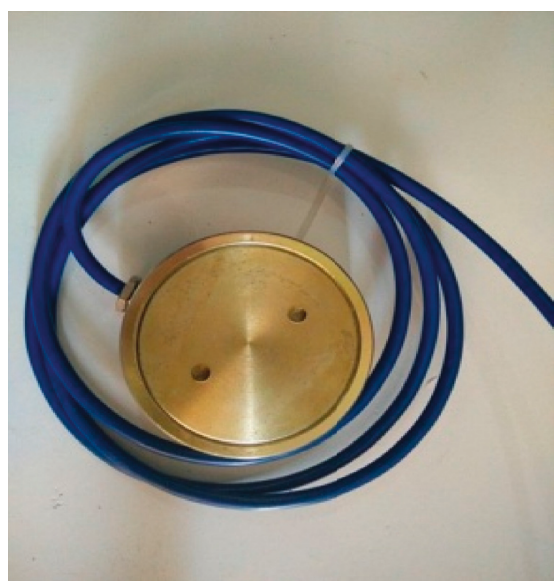

(a)

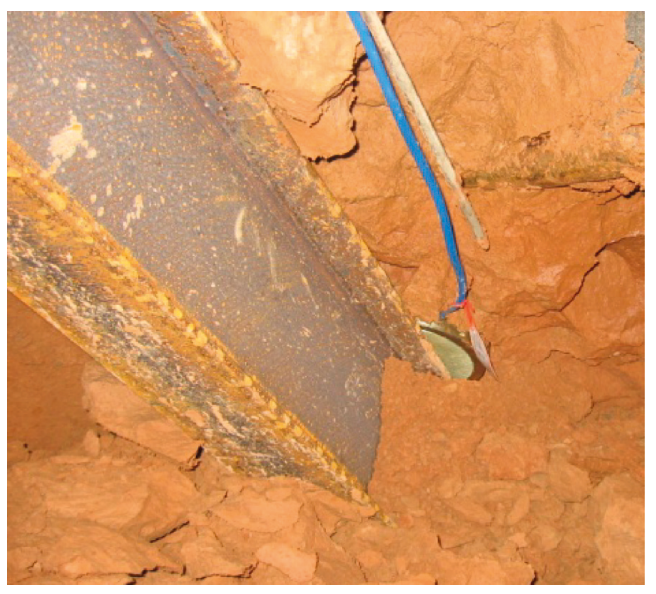

(b)

FIgURE 1: The pressure cell and its conditions: (a) double capsule pressure cell and (b) field installation of pressure cell.

along with the bars, which was fastened with the iron ribbons at $0.5 \mathrm{~m}$ intervening distance.

2.1.3. Surface Strain Gauge. As shown in Figure 3, the internal force of the support steel arch was monitored accurately using surface strain gauges, owing to the axial surface deformation of the steel arch. The surface strain gauge measurement ranged from $-3,000$ to $+3,000 \mu \varepsilon$, and the fullscale precision is $0.5 \%$.

Field installation procedures are shown as the following: Firstly, the special bracket was welded on the inside flange plate of the steel arch. Secondly, the surface strain gauge was welded on the middle of the bracket, which should be coated with a wet towel to avoid frequency drift in the process of the high temperature welding. For the purpose of avoiding the construction disturbance, the gauge was protected by iron-sheet box. Finally, the corresponding frequency value was set as the initial value when the strain value was $0 \mu \varepsilon$.

2.1.4. Distributed Optical Fiber. As shown in Table 1, the optical fiber parameters are listed in this project. Strain- 


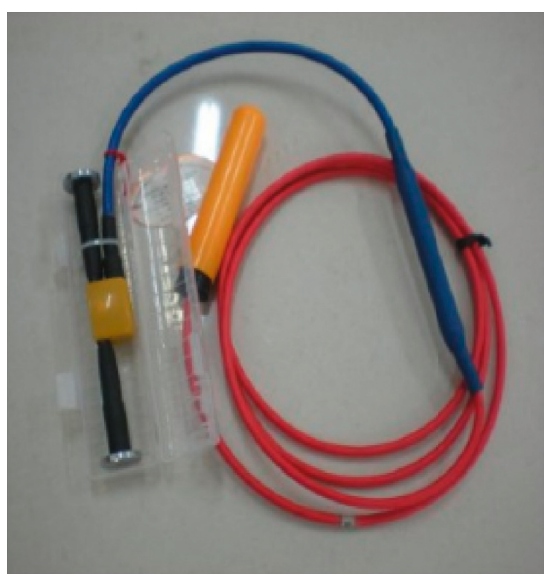

(a)

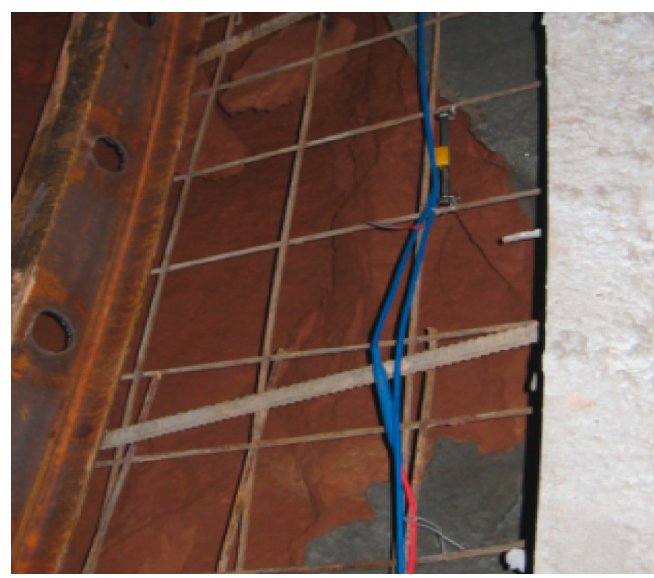

(b)

FIGURE 2: The equipment of concrete strain gauge: (a) concrete strain gauge and (b) field installation of concrete strain gauge.

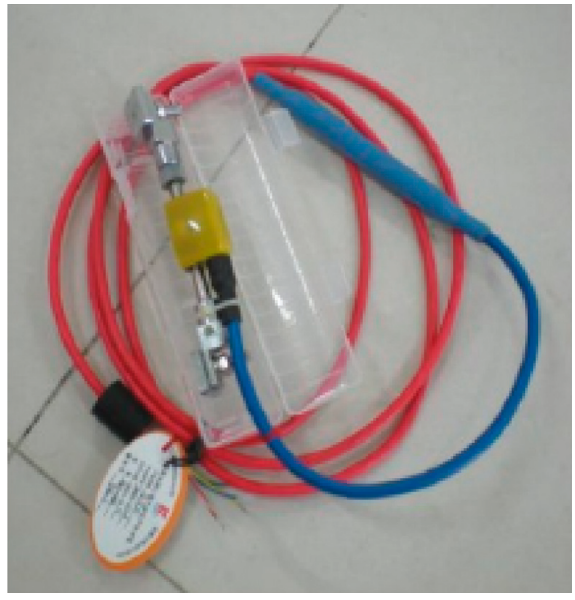

(a)

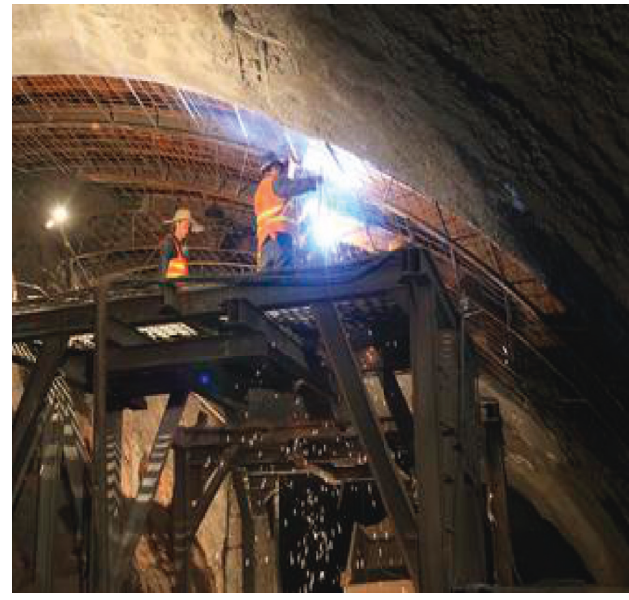

(b)

FIgURE 3: The equipment of surface strain gauge: (a) surface strain gauge and (b) field installation of surface strain gauge.

TABLe 1: Parameters of the optical fiber.

\begin{tabular}{lcccc}
\hline Name & Type & $\begin{array}{c}\text { Diameter } \\
(\mathrm{mm})\end{array}$ & $\begin{array}{c}\text { Weight } \\
(\mathrm{kg} / \mathrm{km})\end{array}$ & $\begin{array}{c}\text { Operating } \\
\text { wavelength } \\
(\mu \mathrm{m})\end{array}$ \\
\hline Sensing optical fiber & NZS-DSS-C07 & 2 & 1.2 & $\begin{array}{c}\text { Refractive } \\
\text { index }\end{array}$ \\
Temperature compensation optical fiber & $\begin{array}{c}\text { NZS-DTS- } \\
\text { C06 }\end{array}$ & 5 & 1.30 to 1.45 & 1.47 \\
\hline
\end{tabular}

sensing optical fiber type is NZS-DSS-C07 with the bare superfine fiber optics (SMG.652b) and the polyurethane (PU) coating. Taking the consistent deformation with a concrete structure, it has a satisfactory elasticity. The armored plastic optical fiber (NZS-DTS-C05) is used for temperature compensation, with an outer diameter of $5 \mathrm{~mm}$ and the measurement range from -20 to $80^{\circ} \mathrm{C}$.

As shown in Table 2, the Brillouin optical time domain reflectometer (BOTDR) is used to debug the distributed optical fiber on the field, which is manufactured by Suzhou Nanzee Sensing Co., Ltd.
Figure 4 shows the construction process of the distributed optical fiber. Specifically, the following steps were involved:

(1) Carving slot: to ensure the installation properly of the sensing cable, the ink line was served as a guide. Then, the slot was carved on the concrete structure with a width of $3 \mathrm{~mm}$ and a depth of $5 \mathrm{~mm}$.

(2) Layout of the sensing cable: the cable was placed in the slot and fixed by the epoxy resin glue. To ensure the coordination deformation between the cable and 
TABle 2: Parameters of the demodulator.

\begin{tabular}{lcccccc}
\hline Type & $\begin{array}{c}\text { Strain accuracy } \\
(\mu \varepsilon)\end{array}$ & $\begin{array}{c}\text { Spatial resolution } \\
(\mathrm{m})\end{array}$ & $\begin{array}{c}\text { Sampling resolution } \\
(\mathrm{m})\end{array}$ & $\begin{array}{c}\text { Max. distance } \\
(\mathrm{km})\end{array}$ & $\begin{array}{c}\text { Measuring time } \\
(\mathrm{s})\end{array}$ & $\begin{array}{c}\text { Max. consumption } \\
(\mathrm{W})\end{array}$ \\
\hline AV6419 & \pm 20 & 0.25 & 0.05 & 80 & 120 to 600 & 120 \\
\hline
\end{tabular}

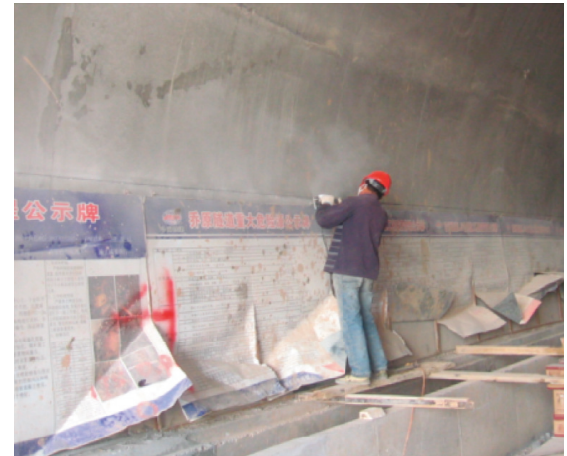

(a)

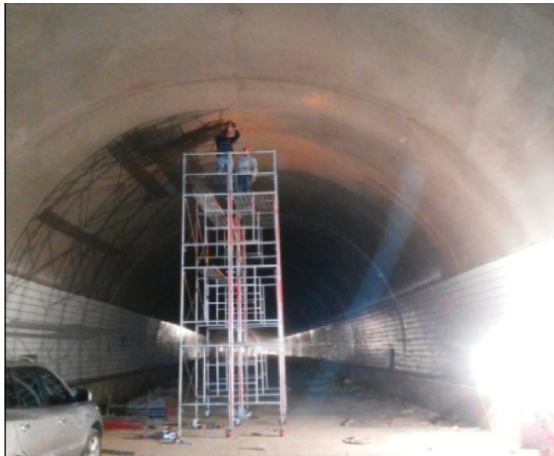

(b)

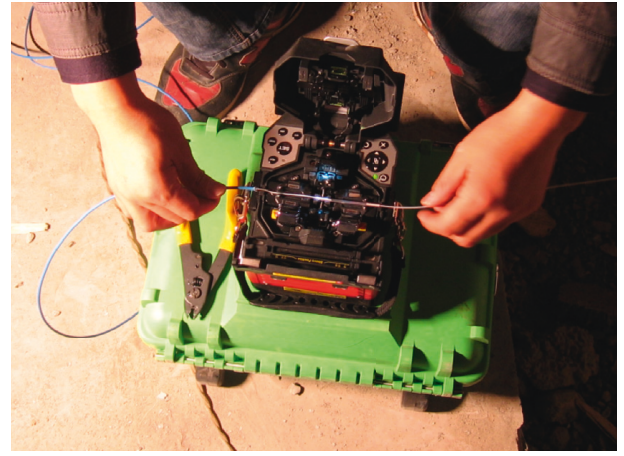

(d)

(c)

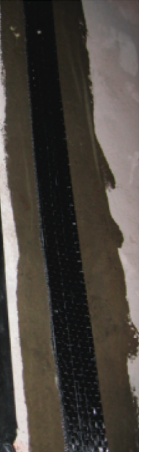

(e)

FIGURE 4: The distributed optical fiber installation flowchart: (a) carving slot and routing on the sidewall, (b) carving slot and routing on the crown, (c) laying of protection layer, (d) fiber splicing, and (e) debugging the light circuit.

the concrete structure, the curing shrinkage ratio of the epoxy resin glue must be less than $2 \%$.

(3) Sticking protective layer: to avoid the exuding of epoxy resin glue, the adhesive tape was stuck on the surface of the slot.

(4) Field debugging: all the sensing cables were connected to be a monitoring network using a fusion splicer. Finally, the complete optical fiber path was debugged by the BOTDR.

\subsection{Experiments}

2.2.1. Engineering Background. Qiaoyuan tunnel is a vital component of the highway from Qingdao to Lanzhou. Qiaoyuan tunnel is located in Qiaoyuan village, Xiangning County, Shanxi Province, China. As shown in Figure 5, there is a loess tableland district with a flat plateau surface. According to the geological survey reports, the stratum structure is divided into two layers simply in a top-down process, which is an aeolian sediment layer of Quaternary 


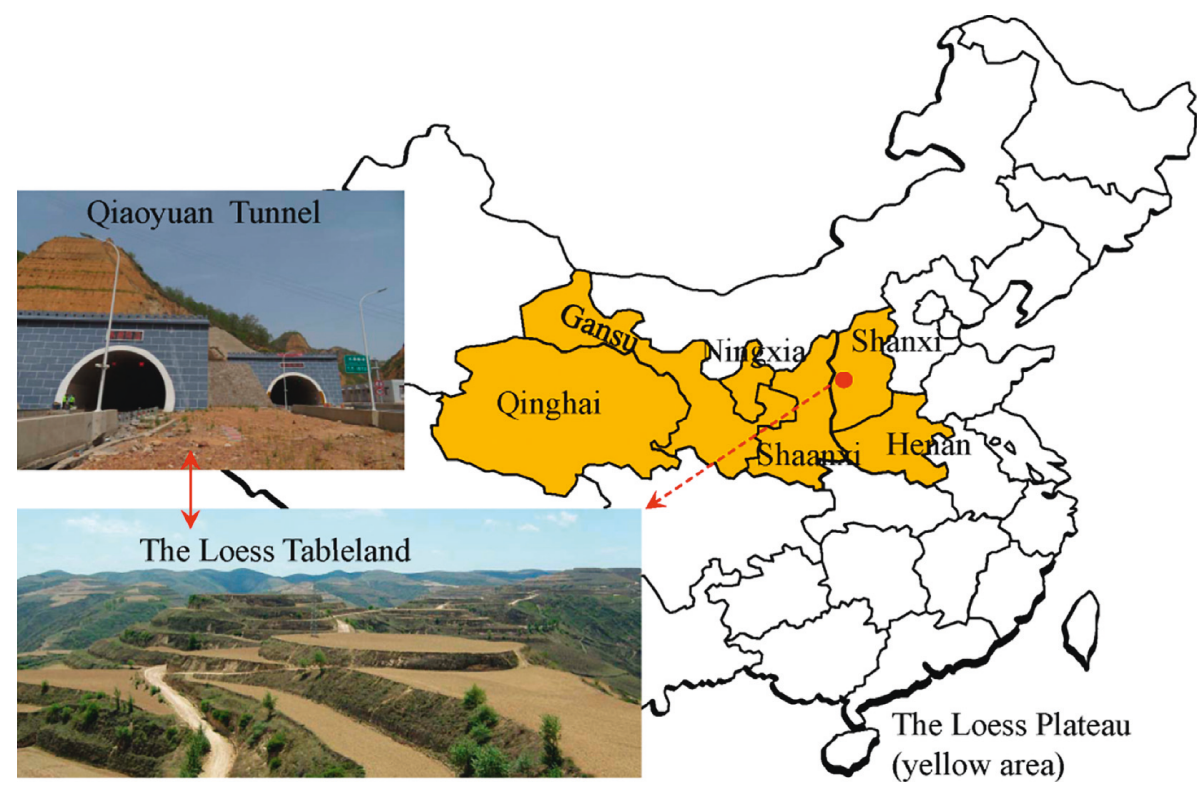

Figure 5: The location and topography of the Qiaoyuan tunnel.

Upper Pleistocene $\left(Q_{3}^{\mathrm{eol}}\right)$ and a drifted deposit layer of Quaternary Middle Pleistocene $\left(Q_{2}^{\mathrm{al}+\mathrm{pl}}\right)$, respectively. The top layer, where the thickness of the loess strata is $6.0 \mathrm{~m}$ to $28.7 \mathrm{~m}$, a class III self-weight collapse loess, developed macropores and vertical joints in the mid-wet state. The water content of loess strata is $6.5 \%$ to $14.5 \%$. Under the depth of $28.7 \mathrm{~m}$, there is a yellow-brown homogeneous old loess layer with tight structure, developed columnar joints and bedding, and small calcareous concretion with the water content of $11.0 \%$ to $17.5 \%$.

As shown in Figure 6, the Qiaoyuan tunnel was influenced by the negative factors of farmland irrigation, transient rainfall, and excavation unloading. There are many geological hazards in the loess strata, from water sinkhole, settlement cave, to ground surface crack, which intensified the deterioration degree of loess surrounding rock. Besides, a vicious circle of the geological hazard is performed. The groundwater sank into the loess strata constantly. The phenomenon of argillization will act on in the surrounding rock of the loess tunnel.

As shown in Figure 7, many sections have undergone collapse of the tunnel face, primary support cracking, and inverted arch cracking as well as the serious deterioration of the surrounding rock evoking the extension of time for completion and increment of the construction cost.

As shown in Figure 8, the Qiaoyuan tunnel is a separated tunnel with uplink and downlink. The uplink and downlink of this tunnel are $1,572 \mathrm{~m}$ and $1,626 \mathrm{~m}$, respectively; excavation is $12.55 \mathrm{~m}$ wide, with a clearance area of $103.7 \mathrm{~m}^{2}$. The tunnel adopts the three-bench and seven-step excavation method when construction gets through the water-rich loess sections. The composite lining is a combination of the primary support and the secondary lining.

As shown in Figure 9, the tunnel support structure presented the primary support including $\Phi 22$ grouted rock bolts, $\Phi 8$ mesh reinforcements, I20a steel arch, and $26 \mathrm{~cm}$
C25 shotcrete. The secondary lining was made of the reinforced C35 concrete.

2.2.2. In Situ Monitoring Schemes. The stress and strain of the surrounding rock, primary support, and secondary liner for water-rich loess tunnel were monitored. The stress of the primary support and surrounding rock was monitored according to "Technical Specifications for Construction of Highway Tunnel (JTG F60-2009).” The stress of secondary liner was evaluated according to "Technical Specification of Maintenance for Highway Tunnel (JTG H12-2015).” The contact pressure, shotcrete stress, and steel arch rib stress were measured by stress box, concrete strain gauge, and surface strain gauge, respectively. Besides, strain state of the secondary liner was measured according to the distributed optical fiber monitoring system.

As shown in Figure 10, the high risk segment YK9 + 660YK9 +710 was selected to be the support engineering. The three sections $(\mathrm{YK} 9+675$, YK9 +690, and YK9 + 705) were monitored by the vibrating wire sensors, which were arranged in the key position of each tunnel section, such as a crown, shoulder, arch-foot, and invert. The arrangement of the key monitoring points on the primary support is illustrated.

As shown in Figure 11, the distributed optical fiber monitoring system was composed of the circular optical fiber, vertical optical fiber, and temperature compensation optical fiber. The distance of the longitudinal interval of two circular optical fibers is $15 \mathrm{~m}$. The vertical optical fiber is arranged on the sidewall, and the distance is $1.5 \mathrm{~m}$ from the floor to the arrangement position. The temperature compensation optical fiber is arranged in the cable trench. In this tunnel, the complete lengths of the strain-sensing fiber and temperature compensation fiber are $104 \mathrm{~m}$ and $50 \mathrm{~m}$, respectively. 


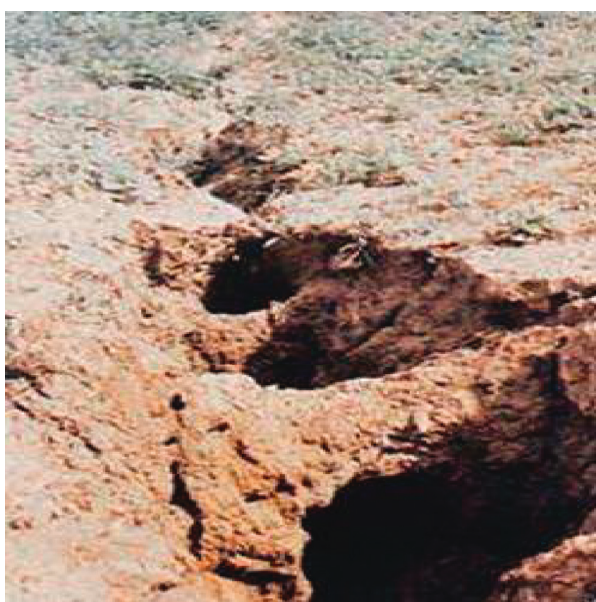

(a)

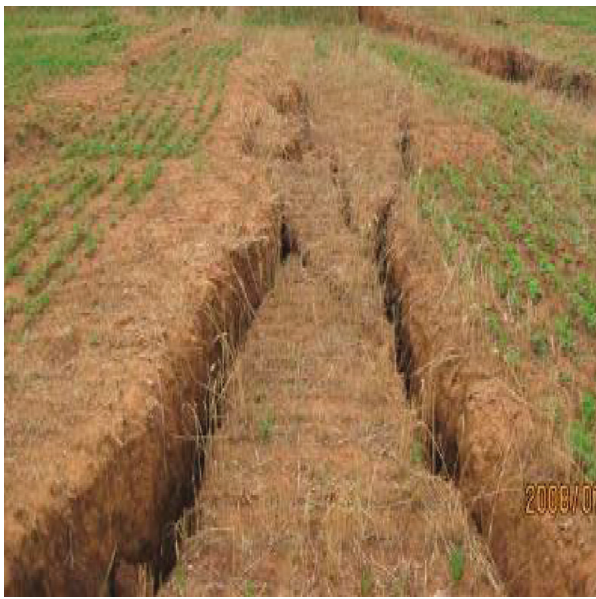

(c)

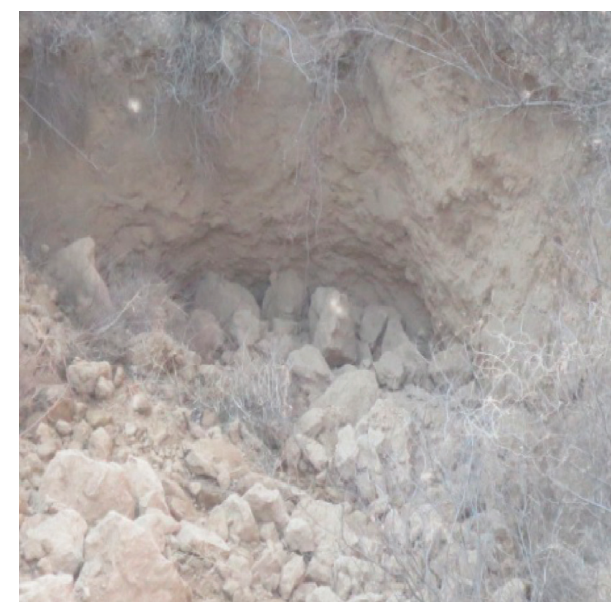

(b)

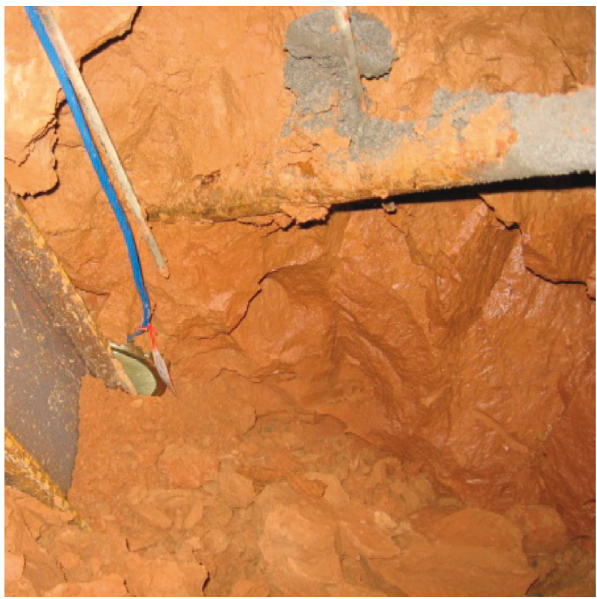

(d)

FIGURE 6: The geological hazard of the water-rich loess tunnel: (a) water sinkhole in ground surface, (b) loess settlement cave, (c) surface crack, and (d) surrounding rock argillization.

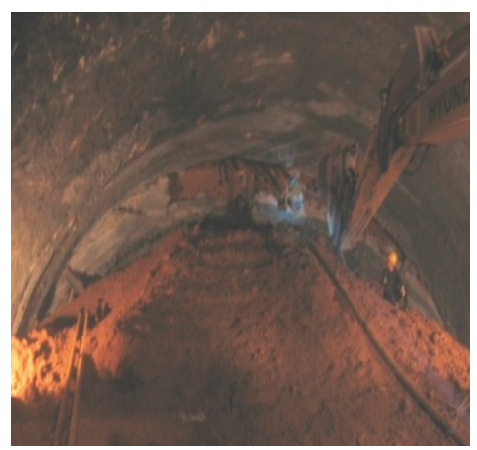

(a)

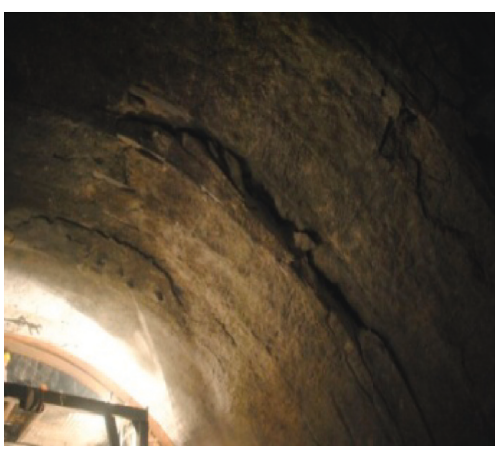

(b)

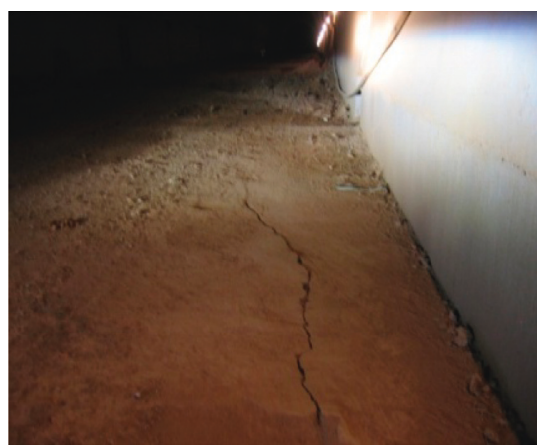

(c)

Figure 7: The damage of the water-rich loess tunnel during construction. (a) Collapse of the tunnel face, (b) primary support cracking, and (c) inverted arch cracking.

\section{Results and Discussions}

3.1. Contact Pressure. As shown in Figure 12, the contact pressure located between the surrounding rock and the primary support structure for section YK9 + 685 was plotted.
The construction procedure and heavy rainfall had a substantial influence on the contact pressure with the effect of excavation unloading. In the early stage, values of measuring point SPC-0 to SPC-6 had increased greatly. Actually, the surrounding rock of loess tunnel has a weak overall stability. 


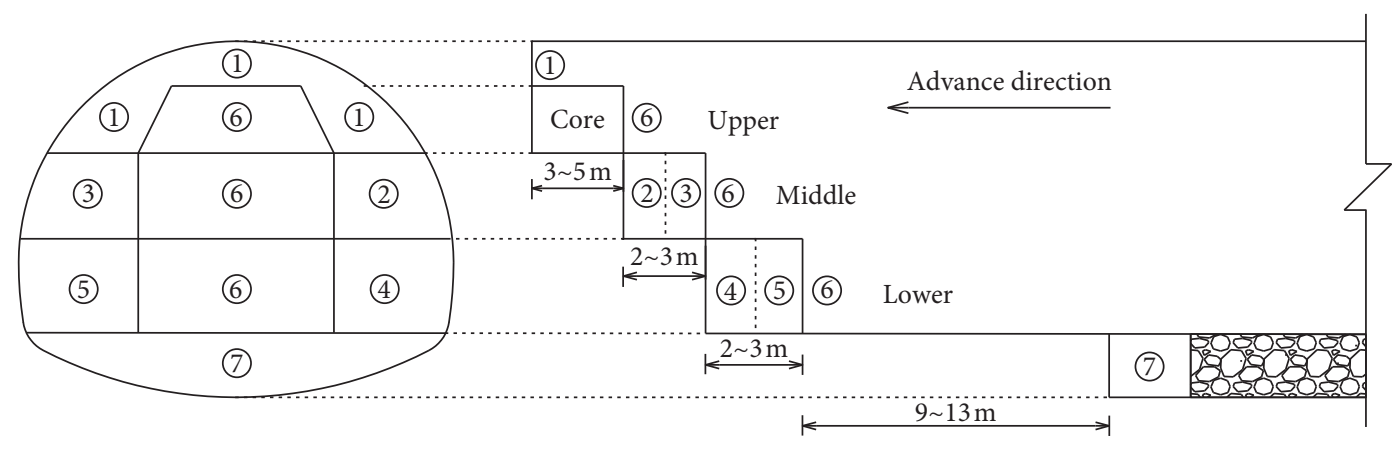

Figure 8: Schematic diagram of the three-bench and seven-step excavation method.

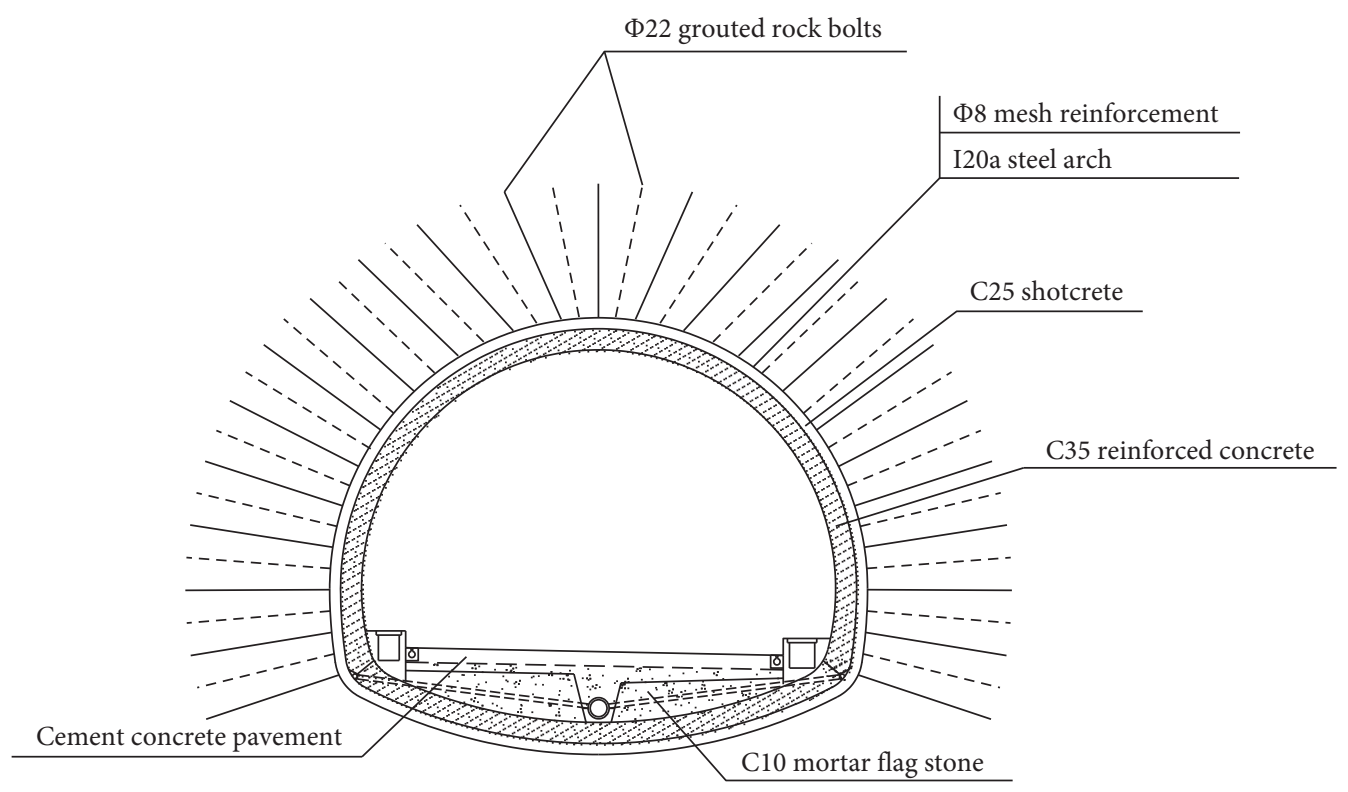

FigURE 9: Schematic diagram of the tunnel support structure.

The plumb joints, fissures, and excavation-free face lead to the rock stress release. Nonetheless, after completion of the tunnel invert, the support structure was constructed in the form of a closed loop and the growth trend of the contact pressure had been relaxed.

There was a heavy rainfall on the tunnel location in the $20^{\text {th }}$ monitoring day, giving rise to the rain runoff infiltration and the increasing of surrounding rock water content. Contract pressure had been increasing drastically on the crown and shoulder with the influence of the water content with a maximum increasing rate of $62 \%$. After completion of tunnel secondary liner, the contract pressure decreased in a small range, which is attributed to that the liner bore the partial load and the load-sharing ratio has changed. In the $52^{\text {nd }}$ monitoring day, the irrigation led to the increase in surrounding rock water content. Therefore, under the interaction of water and soil pressure, the contract pressure increased in a small range.

In the whole monitoring process, all the monitoring points had the changing similar trend upon observation. The arch crown bore the contact pressure at the maximum of $437 \mathrm{kPa}$, which inflicted negative effect on the overall stability of the support structure.
3.2. Shotcrete Stress. As shown in Figure 13, the shotcrete stress was changed with the construction procedure, irrigation, and heavy rainfall at section YK9 +685. It can be seen that the shotcrete stress had an obvious variation in the construction process. After completion of the tunnel secondary liner, the change trend of shotcrete stress was slow. However, there was an irrigation on the ground surface, leading to the remarkable increment of shotcrete stress in the $52^{\text {nd }}$ monitoring day. In particular, shotcrete stress of the left shoulder had risen to $6.21 \mathrm{MPa}$ from $5.30 \mathrm{MPa}$ and the growth rate surpassed 17.2 percent.

Figure 14(a) shows the final stress distribution. The left shoulder of shotcrete bore the compression stress with the maximum of $6.67 \mathrm{MPa}$, which was smaller than the shotcrete ultimate compressive strength $13.5 \mathrm{MPa}$. Nevertheless, the right haunch of shotcrete bore the tensile stress with the maximum of $2.15 \mathrm{MPa}$, exceeding the ultimate tensile strength 1.3 MPa. Apart from that, the tensile stress caused the cracking of the primary support structure in right haunch with a crack width of $3 \mathrm{~mm}$ to $8 \mathrm{~mm}$ (Figure 14(b)). 


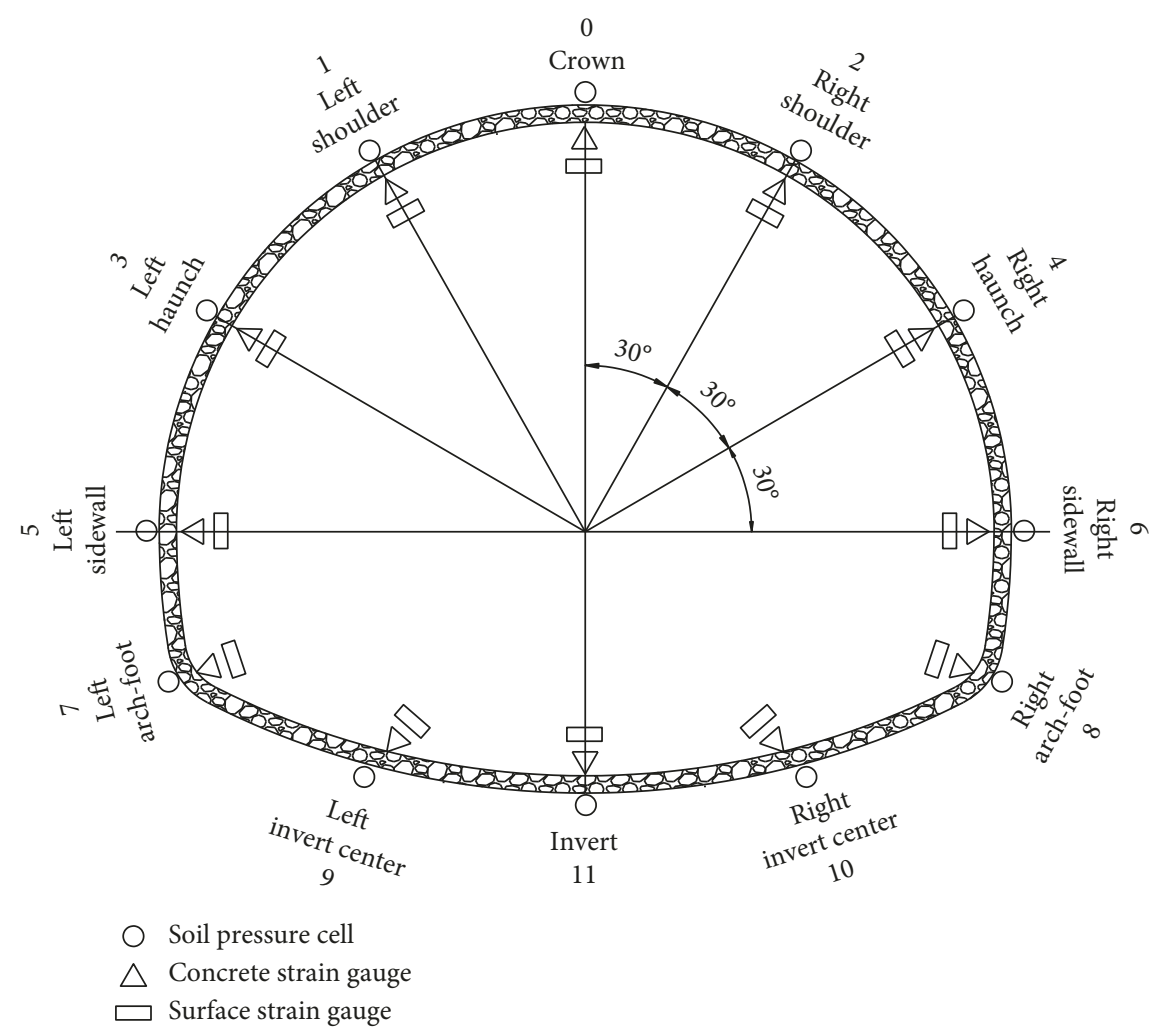

FIgURE 10: Arrangement of the key monitoring points on the primary support.

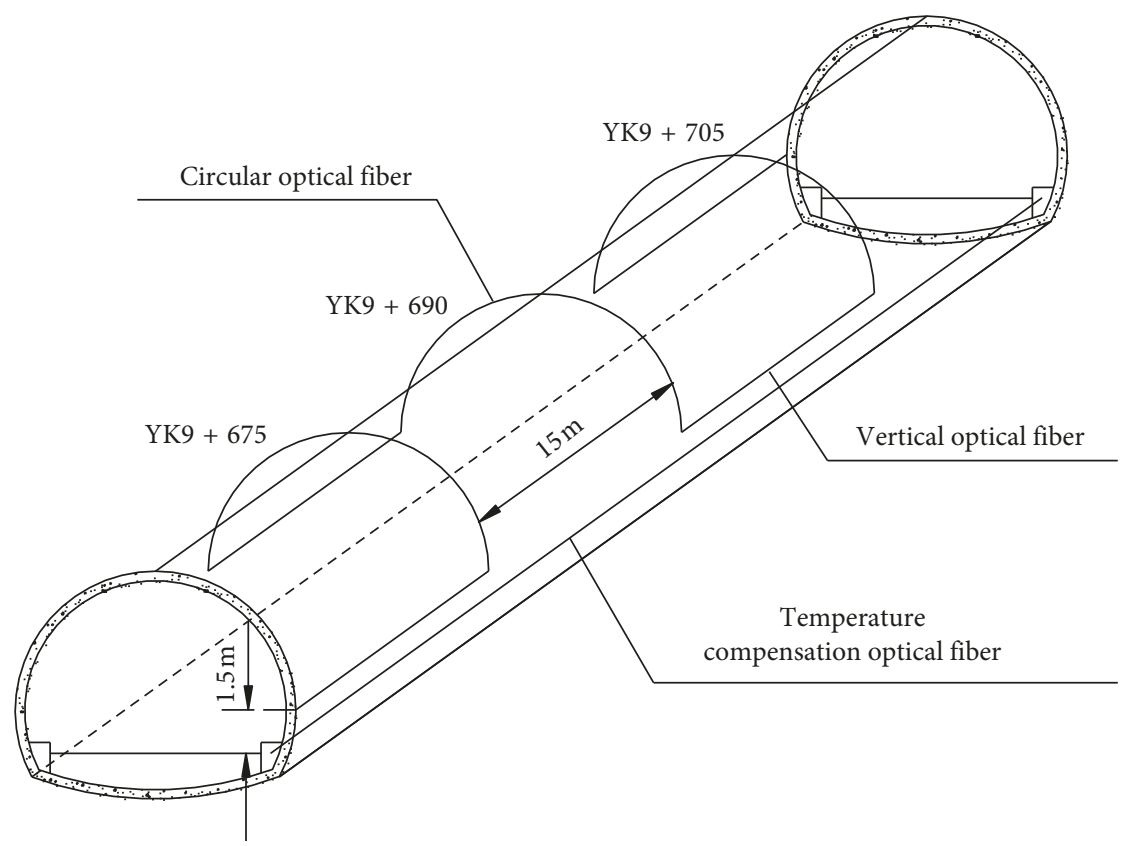

FIGURE 11: Arrangement of the distributed optical fiber.

3.3. Stress of Steel Arch Rib. As shown in Figure 15, the stress variation of steel arch rib was similar to the shotcrete stress, which was affected by the construction procedure, irrigation, and heavy rainfall obviously. The stress of the left haunch had risen to $135.7 \mathrm{MPa}$ after heavy rainfall. Stress had risen to $298.7 \mathrm{MPa}$ after irrigation. The growth rates of stress were $24.6 \%$ and $12.9 \%$, respectively.

As shown in Figure 16, the stress of steel arch rib was unbalanced in terms of the overall distribution. The majority of steel arch rib bore compressive stress and only the 


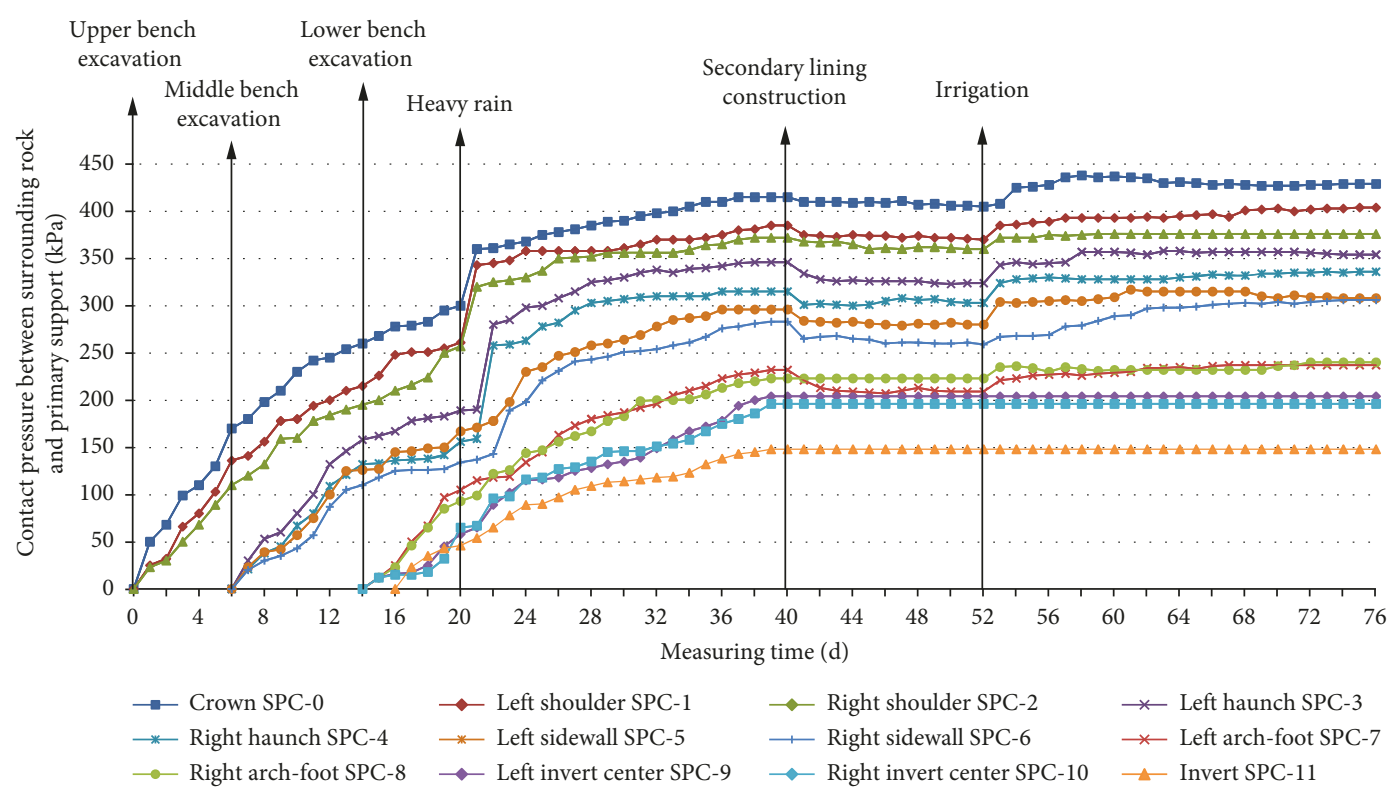

FIGURE 12: Monitoring results of the contact pressure.

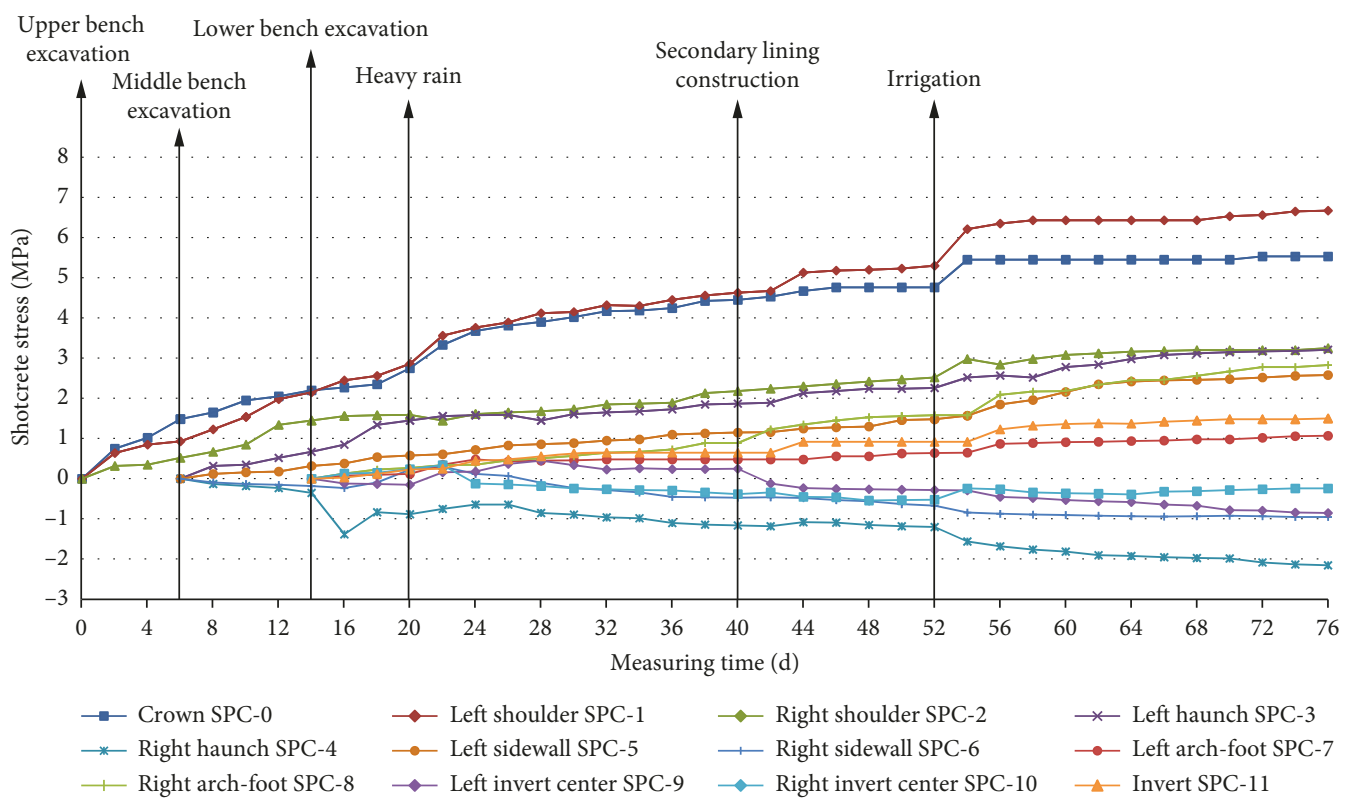

Figure 13: Monitoring results of shotcrete stress (Color figure online).

invert and right shoulder bore tensile stress. There was a tendency of basement uplift. The basic reason was that the ground surface water flowed into back of both sidewalls resulting in that both ends of the basement bore the greater stress, as in "carrying-pole" shape. For the whole steel arch, the maximum compressive stress appeared in the left haunch with the value of $326.6 \mathrm{MPa}$. The maximum tensile stress appeared in the right shoulder with the value of 89.6 MPa, which did not exceed the ultimate compressive and tensile strengths of the steel arch. It was indicated that the steel arch bore the majority the external load, which played an important role of load-bearing on the whole support structure.
3.4. Strain State of the Secondary Liner. In the operation period, the time span of the field monitoring was 9 months and the monitoring frequency was 0.78 times a month. The first measured data are on March 5, 2017, which was set as the initial value.

As shown in Figure 17, in an almost section, the strains changed within 300 to $600 \mu \varepsilon$ and the corresponding crack width was 0.075 to $0.150 \mathrm{~mm}$, which was smaller than the maximum allowable crack width of $0.20 \mathrm{~mm}$. Hence, the structure of the tunnel liner was safe and stable in this section. Nevertheless, there were a series of convex points of the fiber length of $75 \mathrm{~m}$ (the red area of Figure 17), with the strain value of 1,278 to $1,498 \mu \varepsilon$. The corresponding position 


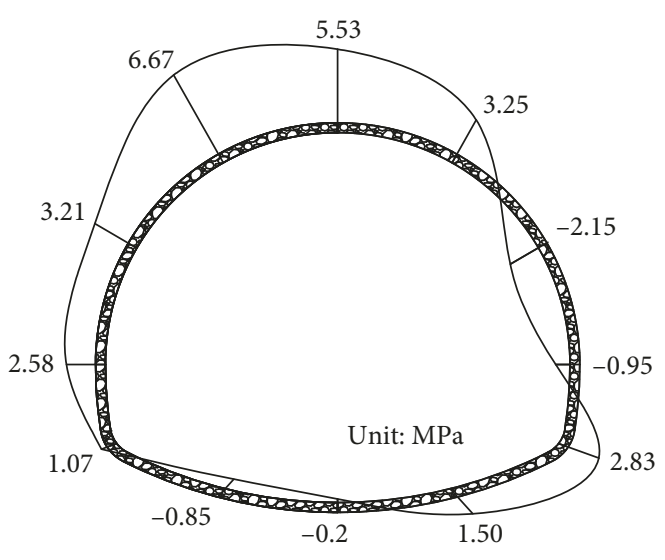

(a)

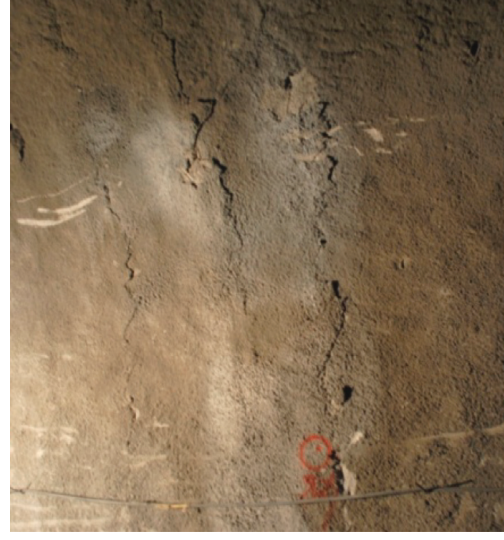

(b)

Figure 14: (a) Finally stress distribution of shotcrete and (b) cracking of the primary support.

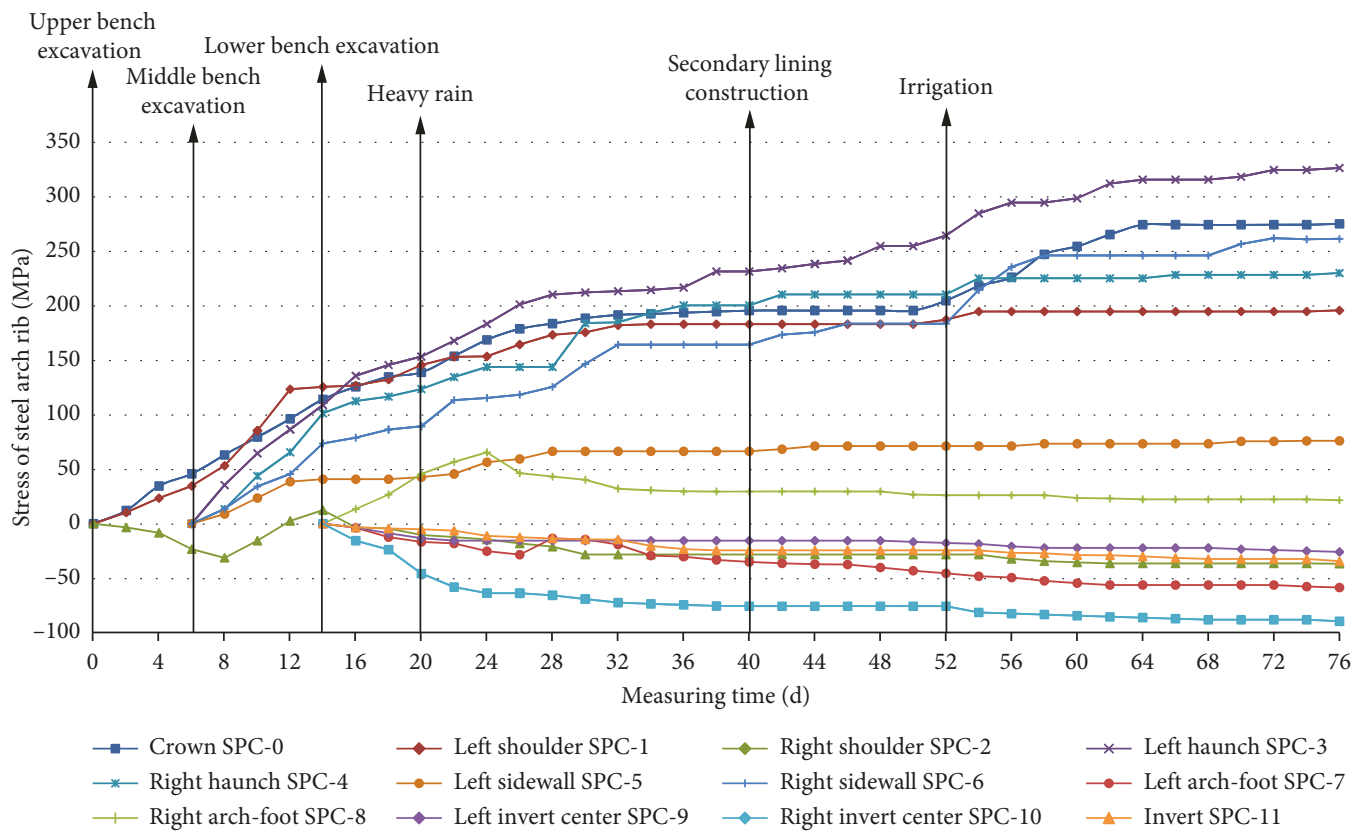

FIgURE 15: Monitoring results of the stress of steel arch rib.

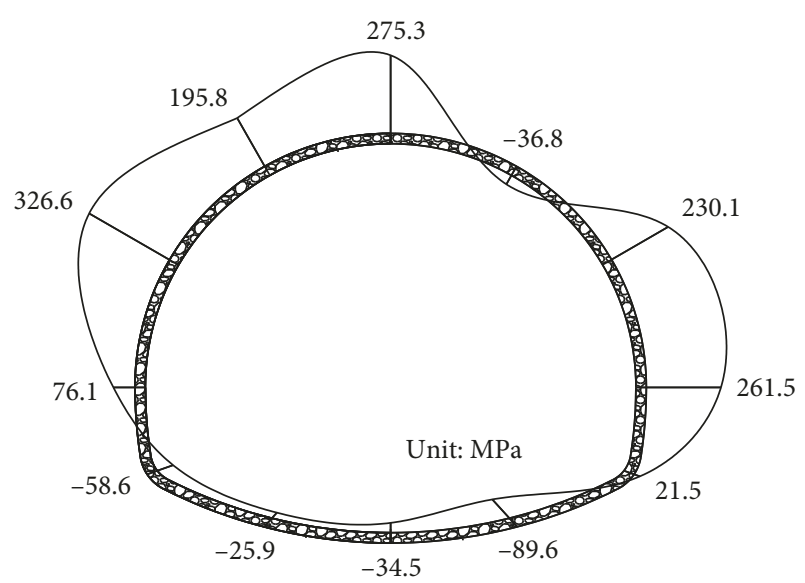

FIGURE 16: Final stress distribution of the steel arch rib. is located at the right sidewall on section YK9 +685 . After calculating, the corresponding crack widths were 0.35 to $0.37 \mathrm{~mm}$, which exceeded the maximum allowable crack width and inflicted a negative effect on the health state of the tunnel supporting structure.

As shown in Figure 18, after a field investigation, it was revealed that there was a circumferential crack with a width of 0.30 to $0.85 \mathrm{~mm}$ identical with the results of the optical fiber monitoring. Furthermore, it can be seen that the strain had risen to $1,489.39 \mu \varepsilon$ of $1,278.80 \mu \varepsilon$ continuously as the days progressed in the red area of Figure 17. In this regard, it was concluded that the crack was still developing and threatened to the safety and stability of the tunnel liner structure. It shall take maintenance measures to prevent the further development of the crack. Furthermore, it will avoid the further decline of the health state of water-rich loess tunnel. 


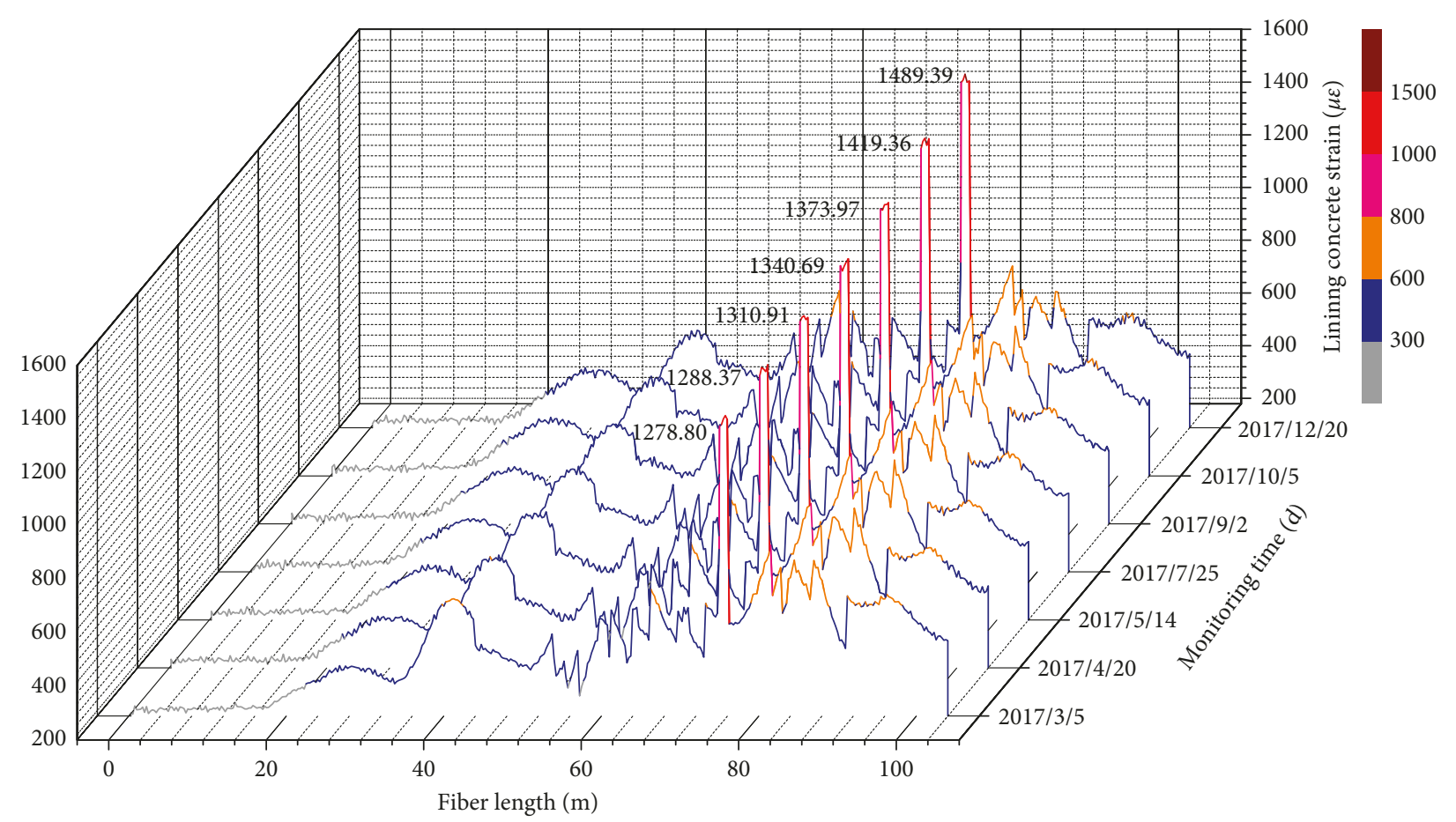

FIGURE 17: Tunnel lining concrete strain time space distribution (Color figure online).

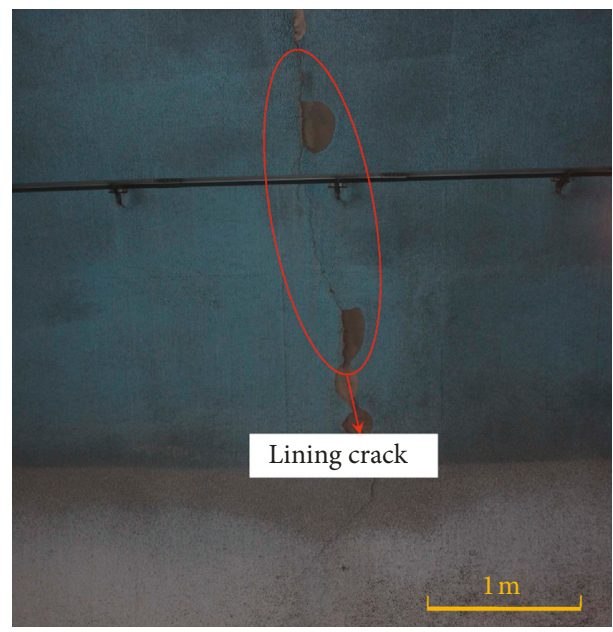

FIgURE 18: Photograph of the lining crack at site.

\section{Conclusion}

Field monitoring of contact pressure, shotcrete stress, stress of steel arch rib, and strain state of the secondary liner was conducted to analyze the health of support structure for the water-rich loess tunnel. Some conclusions are as follows:

(1) Combining the vibrating wire sensor with the distributed optical fiber, the monitoring system has successfully achieved the life-cycle health monitoring of water-rich loess tunnel.

(2) In the tunnel construction period, the nonbalanced distribution stress of the support structure was obviously influenced by the construction procedure, irrigation, and heavy rainfall.
(3) In the tunnel operation period, the distributed optical fiber was used to monitor the strain state of the secondary liner, and it presented a premium performance in the monitoring accuracy of the linear cracks. Moreover, distributed optical fiber had a great significance to maintaining measures and reduced the operational risk as well.

\section{Data Availability}

The data used to support the findings of this study are available from the corresponding author upon request.

\section{Conflicts of Interest}

The authors declare that there are no conflicts of interest.

\section{Acknowledgments}

The authors thank the workers, foremen, and safety coordinators of the main contractors for their participation. The authors also wish to thank engineer Chuanchuan Zhang and Tongsheng Yu for their assistance in gathering field data. This work is financially supported by the Science and Technology Demonstration Project of Transport Ministry in China (grant number 2016009), the Science and Technology Project of Transportation Department in Shanxi Province (grant nos. 2013-1-3 and 2015-1-18), Shanxi Provincial Key Research and Development Program (grant number 201703D111027), and the Special Project of Science and Technology Achievements Transformation Guidance of Shanxi Province (grant number 201804D131034). 


\section{References}

[1] B.-P. Wen and Y.-J. Yan, "Influence of structure on shear characteristics of the unsaturated loess in Lanzhou, China," Engineering Geology, vol. 168, pp. 46-58, 2014.

[2] T. X. Zhu, "Gully and tunnel erosion in the hilly Loess Plateau region, China," Geomorphology, vol. 153-154, pp. 144-155, 2012.

[3] I. Tsaparas, H. Rahardjo, D. G. Toll, and E. C. Leong, "Controlling parameters for rainfall-induced landslides," Computers and Geotechnics, vol. 29, no. 1, pp. 1-27, 2002.

[4] D. Kolymbas and P. Wagner, "Groundwater ingress to tunnels-the exact analytical solution," Tunnelling and Underground Space Technology, vol. 22, no. 1, pp. 23-27, 2007.

[5] P. Arjnoi, J.-H. Jeong, C.-Y. Kim, and K.-H. Park, "Effect of drainage conditions on porewater pressure distributions and lining stresses in drained tunnels," Tunnelling and Underground Space Technology, vol. 24, no. 4, pp. 376-389, 2009.

[6] T. J. Liu, H. H. Zhu, and C. C. Xia, "Analysis of site investigation of cracking and leakage on arcade tunnel lining of Yunnan province," China Journal of Highway and Transport, vol. 17, pp. 64-67, 2004.

[7] H. Mashimo, N. Isago, T. Kitani, and T. Endou, "Effect of fiber reinforced concrete on shrinkage crack of tunnel lining," Tunnelling and Underground Space Technology, vol. 21, no. 34, pp. 382-383, 2006.

[8] A. Ansell, "Investigation of shrinkage cracking in shotcrete on tunnel drains," Tunnelling and Underground Space Technology, vol. 25, no. 5, pp. 607-613, 2010.

[9] S. G. Ran, Q. Jiang, and L. B. Song, "Remote online monitoring technology for underground engineering and its application to Dashizi tunnel, China," Rock and Soil Mechanics, vol. 38, pp. 2137-2156, 2017.

[10] Y. Luo, J. Chen, S. Gao, X. Deng, and P. Diao, "Stability analysis of super-large-section tunnel in loess ground considering water infiltration caused by irrigation," Environmental Earth Sciences, vol. 76, no. 22, pp. 763-780, 2017.

[11] Y. Gao, F. Xu, Q. Zhang, P. He, and Z. Qin, "Geotechnical monitoring and analyses on the stability and health of a large cross-section railway tunnel constructed in a seismic area," Measurement, vol. 122, pp. 620-629, 2018.

[12] J.-P. Yang, W.-Z. Chen, M. Li, X.-J. Tan, and J.-X. Yu, "Structural health monitoring and analysis of an underwater TBM tunnel," Tunnelling and Underground Space Technology, vol. 82, pp. 235-247, 2018.

[13] P. Li, Y. Zhao, and X. Zhou, "Displacement characteristics of high-speed railway tunnel construction in loess ground by using multi-step excavation method," Tunnelling and Underground Space Technology, vol. 51, pp. 41-55, 2016.

[14] L. Ran, X. W. Ye, and H. H. Zhu, "Long-term monitoring and safety evaluation of a metro station during deep excavation," Procedia Engineering, vol. 14, pp. 785-792, 2011.

[15] Y. Xue, X. Zhang, S. Li et al., "Analysis of factors influencing tunnel deformation in loess deposits by data mining: a deformation prediction model," Engineering Geology, vol. 232, pp. 94-103, 2018.

[16] Y.-h. Li, S.-d. Xu, and J.-p. Liu, "A new convergence monitoring system for tunnel or drift based on draw-wire displacement sensors," Tunnelling and Underground Space Technology, vol. 49, pp. 92-97, 2015.

[17] F. Ariznavarreta-Fernández, C. González-Palacio, A. MenéndezDíaz, and C. Ordoñez, "Measurement system with angular encoders for continuous monitoring of tunnel convergence,"
Tunnelling and Underground Space Technology, vol. 56, pp. 176-185, 2016.

[18] B. Zhou, X. Xie, and Y. Li, "A structural health assessment method for shield tunnels based on torsional wave speed," Science China Technological Sciences, vol. 57, no. 6, pp. 1109-1120, 2014.

[19] H.-w. Huang, Q.-t. Li, and D.-m. Zhang, "Deep learning based image recognition for crack and leakage defects of metro shield tunnel," Tunnelling and Underground Space Technology, vol. 77, pp. 166-176, 2018.

[20] E. Menendez, J. G. Victores, R. Montero, S. Martínez, and C. Balaguer, "Tunnel structural inspection and assessment using an autonomous robotic system," Automation in Construction, vol. 87, pp. 117-126, 2018.

[21] L. Tasker, A. Karrech, J. Shragge, and M. Josh, “Time-lapse monitoring of internal alteration of a concrete structure using ground penetrating radar," Construction and Building Materials, vol. 191, pp. 300-310, 2018.

[22] F. Luo, "Application of geological radar in health diagnosis of tunnel, China," Journal of Chang'an University (Natural Science Edition), vol. 26, pp. 51-54, 2006.

[23] D. Li, C. Li, and Y. G. Zhao, "Application of seismic CT and FBG sensor techniques to tunnel structure diagnosis, China," Journal of Engineering Geology, vol. 16, pp. 839-843, 2008.

[24] H. Q. Li, C. J. Lu, and F. P. Gan, "CT identification of karst rock structure damage and diagnosis, forecasting and early warning of ground collapse and water inrush in tunnel-a case study of Yangpeng tunnel of Beijing-Zhuhai expressway in northern Guangdong, China," Chinese Journal of Rock Mechanics and Engineering, vol. 33, pp. 763-771, 2014.

[25] K. Fujihashi, K. Kurihara, K. Hirayama, and S. Toyoda, "Monitoring system based on optical fiber sensing technology for tunnel structures and other infrastructure," Sensing Issues in Civil Structural Health Monitoring, vol. 10, pp. 185-195, 2005.

[26] B. Shi, X. J. Xu, and D. Wang, "Study on BOTDR-based distributed optical fiber strain measurement for tunnel health diagnosis, China," Chinese Journal of Rock Mechanics and Engineering, vol. 24, pp. 2622-2628, 2005.

[27] J. H. Mao, Y. He, and W. L. Jin, "Life-cycle stress monitoring method for tunnel secondary lining based on distributed optical fiber sensor, China," Chinese Journal of Rock Mechanics and Engineering, vol. 24, pp. 2622-2628, 2005.

[28] M. Fajkus, J. Nedoma, P. Mec, E. Hrubesova, R. Martinek, and V. Vasinek, "Analysis of the highway tunnels monitoring using an optical fiber implemented into primary lining," Journal of Electrical Engineering, vol. 68, no. 5, pp. 364-370, 2017.

[29] X. Wang, B. Shi, G. Wei, S.-E. Chen, H. Zhu, and T. Wang, "Monitoring the behavior of segment joints in a shield tunnel using distributed fiber optic sensors," Structural Control and Health Monitoring, vol. 25, no. 1, pp. e2056-2071, 2018. 


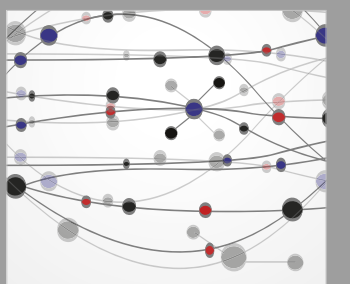

The Scientific World Journal
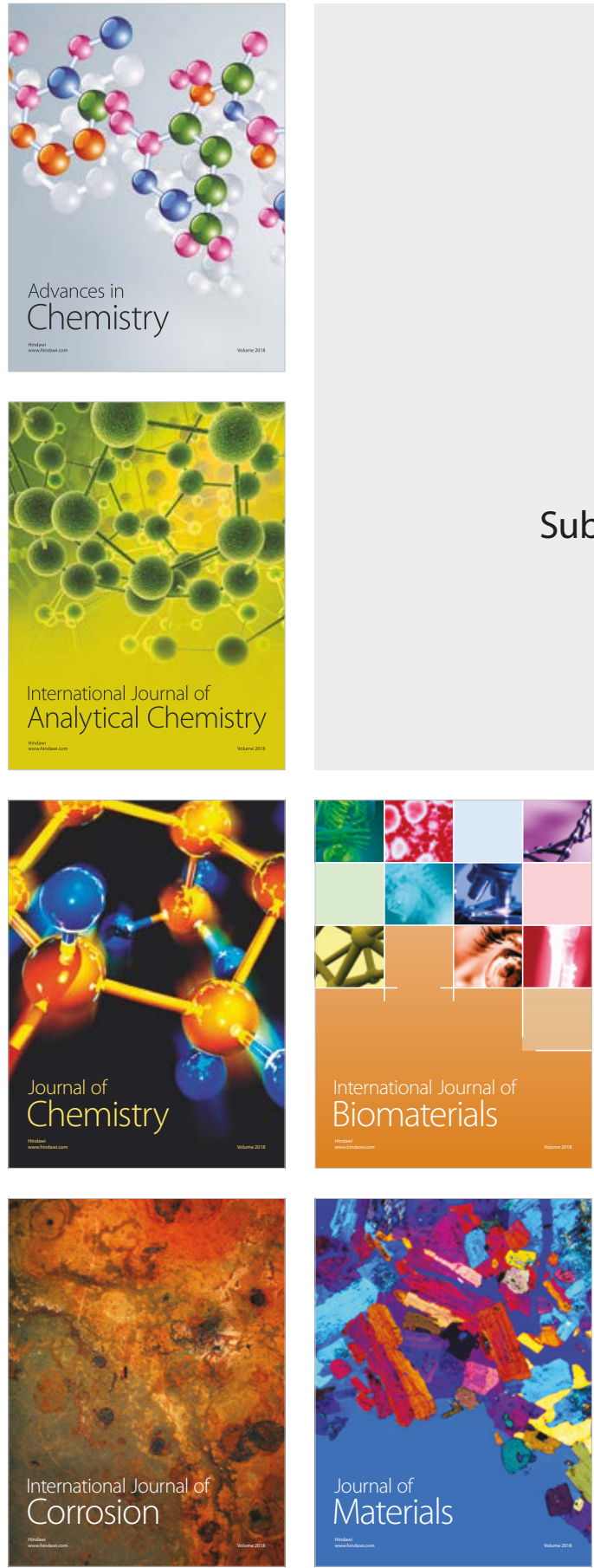

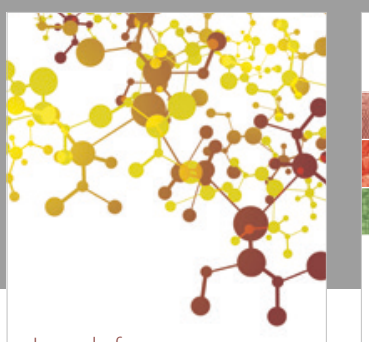

Journal of

Applied Chemistry
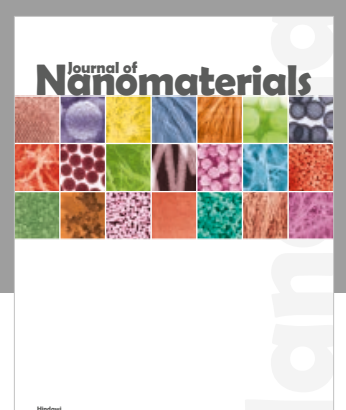

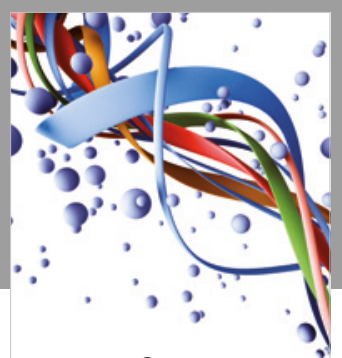

Scientifica

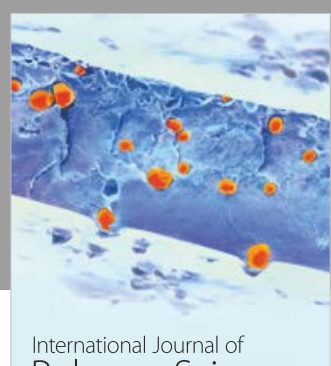

Polymer Science

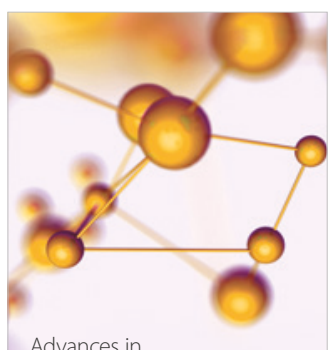

Physical Chemistry
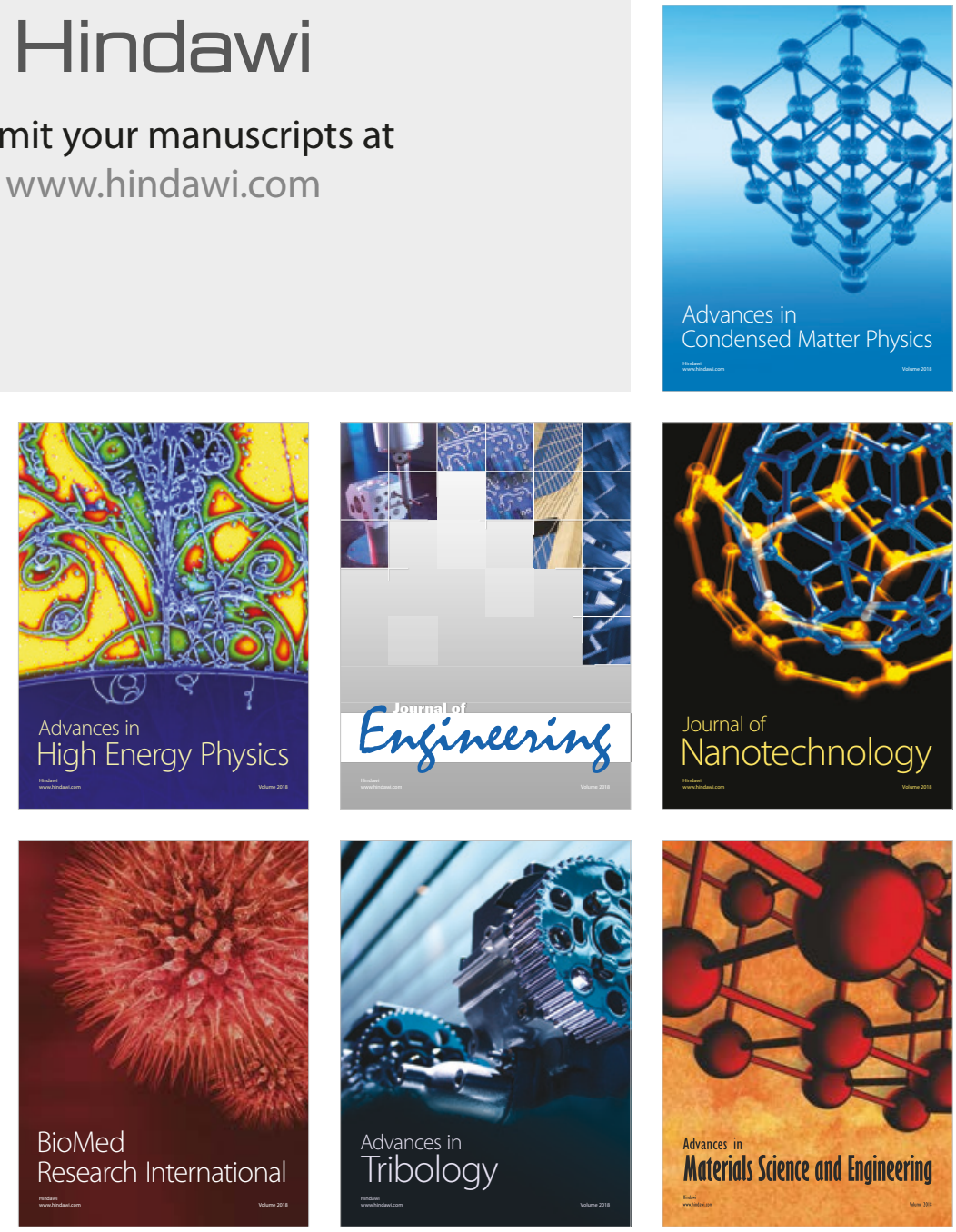